ORIENTAL JOURNAL OF CHEMISTRY

An International Open Free Access, Peer Reviewed Research Journal

www.orientjchem.org
ISSN: 0970-020 X

CODEN: OJCHEG

2014, Vol. 30, No. (2):

Pg. 485-489

\title{
Linseed (Linum usitatissimum L.) as a Biocatalyst for Reduction of Nitroaromatic Compounds
}

\section{LEONARDO C. TAVARES ${ }^{1}$, TELMA LEDA G. DE LEMOS ${ }^{1}$, ANGELA MARTHA C. ARRIAGA ${ }^{1 *}$, MARIA VALDELINE S. TEIXEIRA ${ }^{1}$, GILVANDETE MARIA P. SANTIAGO ${ }^{1,2}$ and DANIELE A. FERREIRA ${ }^{1}$}

\begin{abstract}
1Programa de Pós-Graduação em Quimica, Departamento de Química Orgânica e Inorgânica, Universidade Federal do Ceará, 60451-970 Fortaleza - CE, Brazil.

Departamento de Farmácia, Universidade Federal do Ceará, 60430-370 Fortaleza - CE, Brazil.

*Corresponding author E-mail: ang@.ufc or angelamcarriaga@yahoo.com.br
\end{abstract}

http://dx.doi.org/10.13005/ojc/300211

(Received: April 10, 2014; Accepted: May 22, 2014)

\begin{abstract}
The reduction of nitroaromatic compounds is an important transformation that be used in the synthesis of amines which are interesting intermediates of pharmaceuticals and other derivatives. Linseed, Linum usitatissimum L., were used to catalyze biotransformations of nitrobenzene, ortho-nitroacetophenone, meta- nitroacetophenone and para-nitroacetophenone. Ortho-aminoacetophenone, and para- aminoacetophenone were obtained with excellent chemoselectivity (92.1 to $\geq 99 \%$ ).
\end{abstract}

Key words: Linum usitatissimum L, Linseed, Bioreduction, Nitroaromatic Compounds, Chemoselectivity.

\section{INTRODUCTION}

Nitroaromatic compounds are released into the biosphere in the form of chemical or biological waste, but others, that are used as synthetic intermediates, pesticides, explosives, antibiotics, etc. ${ }^{1,2}$. Although a few nitroaromatic compounds are from natural source, such as chloramphenicol and some plants of the genus Astragalus synthesize nitro glycosides as a defense mechanism ${ }^{3-4}$. However, the vast majority of nitroaromatic compounds are derived from anthropogenic sources, mainly as a result of industrial processes ${ }^{1}$. This class, including nitrofurans, nitropyrenos, nitrobenzenes and various others, is the precursor to the corresponding amines by reduction and has been used in various applications such as pharmaceuticals, antimicrobial agents, food additives and materials in various industrial processes, such as production of plastics, 
explosives, dyes and agricultural products, etc. ${ }^{1,5-7}$. Since the last century, large areas of soil and groundwater have been heavily contaminated by xenobiotics, thus, several articles have specially addressed the effective forms of biodegradation or biotransformation of these serious environmental contaminants ${ }^{8-10}$.

Therefore, nitrocompounds have attracted considerable attention because of their potential risk to human health ${ }^{11}$. Nevertheless, the use of these compounds has never discontinued since continued being used in various therapeutic classes, such as antibacterial, anti-inflammatory, antihypertensive, antineoplastic and used in veterinary medicine ${ }^{12-14}$.

Enzymatic reduction is essential for nitrocompounds to exert their therapeutic and/or cytotoxic effects and most of these compounds have been subjected to bioreduction by microorganisms such as bacteria and fungi ${ }^{2,8}$. The nitroreduction is the initial step in the catabolism of a variety of nitroaromatic compounds $s^{1,15}$. The nitroreductase comprise a family of evolutionarily conserved proteins that were originally discovered in eubacteria $^{15}$. These enzymes are able to catalyze the reduction of the nitro group using and flavin mononucleotide (FMN) or flavin adenine dinucleotide (FAD) as a prosthetic group, and nicotinamide adenine dinucleotide $(\mathrm{NAD}(\mathrm{P}) \mathrm{H})$ as reducing agent ${ }^{16}$. These proteins have attracted a great interest and environmental importance to human health, decreasing the toxicity of nitrocompounds, as well as, being applied in biotechnology, bioremediation and biocatalysis ${ }^{17-18}$.

Studies report biotransformation of nitroaromatic compounds using Arracacia xanthorrhiza and Beta vulgaris associated with a microorganism Candida guilliermondii, coconut water which were converted into amines and to the corresponding acetamides. Some plants, as Lens culinaris seeds, are also reported as a biocatalyst for reducing nitro groups ${ }^{19-21}$.

Linum usitatissimum L., flaxseed or linseed has a high content of polyunsaturated omega-3 fatty acids, such as $\alpha$-linolenic acid. It is considered good source of protein, dietary fiber, as well as, of phenolic acids, flavonoids, vitamins and minerals with antioxidant, antimicrobial and anticancer activities; being used as a functional food for prevention of cardiovascular diseases ${ }^{22}$.

The reduction of nitrocompounds is important in the production of amines, which can be used as pharmaceutical intermediates ${ }^{21}$. In recent years, plant parts and microorganisms have been related as a green alternative to reduce nitroaromatic compounds $9,17,21,23$. Therefore, in the order to find new sources of nitroreductases, we investigated the use the whole seeds of Linum usitatissimum $\mathrm{L}$. for the bioreduction of nitroaromatic substrates (Scheme 1). Then, this work can provide a promising agent for the bioreduction of the nitro group.

\section{MATERIAL AND METHODS}

\section{Plant material}

Commercial seeds of Linum usitatissimum

L. were purchased in a local market. Botanical identification data were provided by the Celeiro Alimentos e Produtos Naturais Ltda. (celeiro@ celeiroalimentos.com.br).

\section{General Experimental Procedure}

The nitroaromatic compounds (1-4) were obtained from Sigma-Aldrich provider. Whole seeds of Linum usitatissimum L. were washed with $5 \%$ sodium hypochlorite and rinsed with sterile distilled water. Each nitroaromatic compounds substrate, 14 , (50 mg), were added to a suspension of $20 \mathrm{~g}$ of $L$. usitatissimum L. seeds in a $40 \mathrm{~mL}$ of a buffered solution $\left(\mathrm{Na}_{2} \mathrm{HPO}_{4} / \mathrm{KH}_{2} \mathrm{PO}_{4}\right), \mathrm{pH} 6.0$, and incubated at $25^{\circ} \mathrm{C}$, in an orbital shaker (175 rpm) for 72 hours. All biotransformation reactions were performed using the methodology proposed by Machado et. al. modified $^{24}$. The reactions were performed in triplicate. The course of all reactions was monitored by TLC (Merck, Silica gel $60 \mathrm{~F}_{254}$ ) and the substances revealed by spraying with vanillin solution. After completion of the reaction, the each suspension was filtered, washed with water and the aqueous solutions were extracted with $\mathrm{CH}_{2} \mathrm{Cl}_{2}(3 \times 50 \mathrm{~mL})$. The organic phases were dried with $\mathrm{Na}_{2} \mathrm{SO}_{4}$ and removed in a rotator evaporator. The reaction products were purified by column chromatography on silica gel 60 VETEC, with a binary mixture of hexane/ethyl acetate $(8: 2, v / v)$ as eluent. 
All reaction products were analyzed by High Performance Liquid Chromatography (HPLC) of Shimadzu, L201147 pump equipped with a chiral columns $\mathrm{OB}-\mathrm{H}$ and $\mathrm{AS}-\mathrm{H}$, mobile phase binary mixture of $n$-hexane/isopropyl alcohol (90:10 by $80: 20$ ) ranging the composition of the same according to the needs of the sample, and Shimadzu UV-Vis detector SPD-M20A. The mass spectra were obtained using a Shimadzu gas chromatograph GC-2010 plus model coupled to a mass spectrometer of Shimadzu GCMS-QP model SE 2010, using a column with a stationary phase of $95 \%$ dimethylpolysiloxane/5\% diphenylpolysiloxane with a length of $30 \mathrm{~m}$, internal diameter $0.25 \mathrm{~mm}$, outer diameter of $0.39 \mathrm{~mm}$ and $0.25 \mu \mathrm{m}$ of film thickness and an auto-injector of Shimadzu AOC-20i model. The mobile phase was helium. The values of conversion and enantiomeric excess of biocatalytic reactions were calculated by calibration curve of the starting substrate and the final product prepared in HPLC and verified with mass spectra.
The optical rotation of the product (S)-1(3-aminophenyl)ethanol (3) was measured in digital Perkin-Elmer 241 and compared with the literature data ${ }^{25}$.

\section{RESULTS AND DISCUSSION}

The biocatalytic reductions of nitroaromatic compounds, nitrobenzene (1), onitroacetophenone (2), $m$-nitroacetophenone (3) and $p$-nitroacetophenone (4) were performed using whole seeds of Linum usitatissimum L. (Table 1). The compounds were converted into the corresponding amines in good concentrations, with exception of substrate 3 . The reactions of bioreductions of the compounds 1, 2 and 4 shown high values of conversion of a nitro group to amino group $(92.1 \% \geq 99 \%$ and $98.1 \%$, respectively), then the steric influence was not observed due the presence of the substituents on aromatic ring as observed when the Lens culinaris was used as biocatalyst ${ }^{21}$. These ones for the compounds 2 and

Table 1: Results of reductions of nitroaromatic compounds (1-4) using the seeds of Linum usitatissimum $\mathrm{L}$

\begin{tabular}{lccc}
\hline Substrates & $\begin{array}{c}\text { Bioconversion } \\
\text { and alcohol (\%) }\end{array}$ & $\begin{array}{c}\text { Bioconversion amine } \\
\text { amine (\%) }\end{array}$ & $\begin{array}{c}\text { ee } \\
\text { (\%) }\end{array}$ \\
\hline 1 & 92.1 & - & - \\
2 & $\geq 99.0$ & - & - \\
3 & 21.6 & 40.5 & 8.7 \\
4 & 98.1 & - & - \\
\hline
\end{tabular}

4 shown high chemoselectivity, the carbonyls were unaffected and only the aromatic amine was produced. Chemoselectivity was also observed in some reactions with vegetables ${ }^{20,26}$ but only the carbonyl was reduced; also the literature reports the bioreduction of nitroaromatic compounds ${ }^{21}$ but with the rather modest yields. Finally, the reaction of substrate 3 , with the Linum usitatissimum $\mathrm{L}$. seeds, gave rise to 3-amino-acetophenone (3a) and (S)-1-(3-aminophenyl)ethanol (3b) as products, with values of conversion of $21.6 \% \mathrm{e}$ $40.5 \%$, respectively. The presence of a carbonyl group, above all when it is in para or ortho position, that decreases the electron deficiency in nitroaromatic ring, appears favor the reduction of the nitro group ${ }^{19}$. In addition, we observed low enantioselectivity ( $8.7 \%$ ) of the product alcohol (3b) with the $S$ configuration, which is in agreement with Prelog rule 24,26 .

Linum usitatissimum L. seeds showed a suitable biocatalyst for the preparation of aromatic amines of industrial and pharmaceutical interest from nitroaromatic compounds, with an excellent chemoselectivity ( 92.1 to $\geq 99 \%$ ). When a carbonyl is located in meta position relative to the nitro group, it was also reduced with a medium conversion (21.6 and $40.5 \%$ ) and low enantioselectivity (8.7\%). The results obtained suggest that $L$. usitatissimum $L$. has a nitroreductase system that is responsible for 
the reductions observed, and it can be considered a potential biocatalyst for applications in academic organic synthesis, as well as, in the chemical and pharmaceutical industries.

\section{Aminobenzene (1)}

GC-MS m/z (\%) $93\left(\mathrm{M}^{+}, \mathrm{C}_{6} \mathrm{H}_{7} \mathrm{~N} ; 100\right), 93$ (100), 66 (50); 39 (15) HPLC: Chiralcel OB-H, 30C, $n$-hexane/isopropyl alcohol (95:5), $0.8 \mathrm{~mL} / \mathrm{min}, \mathrm{t}_{\mathrm{R}}$ (min): 12.2 .

\section{2-aminoacetophenone (2)}

GC-MS m/z (\%) $135\left(\mathrm{M}^{+}, \mathrm{C}_{8} \mathrm{H}_{9} \mathrm{NO} ; 80\right), 120$ (100), 92 (50), 65 (30), 39 (10); HPLC: Chiralcel AS-H, $35^{\circ} \mathrm{C}, n$-hexane/isopropyl alcohol (80:20), $1 \mathrm{~mL} / \mathrm{min}$, $t_{R}(\min ): 9.4$.

\section{3-aminoacetophenone (3a)}

GC-MS m/z (\%) $135\left(\mathrm{M}^{+}, \mathrm{C}_{8} \mathrm{H}_{9} \mathrm{NO} ; 90\right), 120$ (90), 92 (100), 65 (40), 39 (15); HPLC: Chiralcel OB-H, 30ㄷ, $n$-hexane/isopropyl alcohol (95:5), 0.5 $\mathrm{mL} / \mathrm{min}, \mathrm{t}_{\mathrm{R}}(\min ): 17.3$.<smiles>CC(=O)c1ccc(N)cc1</smiles>

Scheme 1: Bioreduction of nitroaromatic compounds (1-4) using Linum usitatissimum L. seeds

\section{(S)-1-(3-aminophenyl)ethanol (3b)}

$$
[\alpha]^{20}{ }_{0}-5.8^{\circ} \text { (c. } 0.01, \mathrm{CHCl}_{3} \text { ); GC-MS } \mathrm{m} / \mathrm{z}(\%)
$$

$137\left(\mathrm{M}^{+}, \mathrm{C}_{8} \mathrm{H}_{11} \mathrm{NO}\right.$; 25), 119 (100), 94 (50), 39 (10); HPLC: Chiralcel AS-H, $30^{\circ} \mathrm{C}, n$-hexane/isopropyl alcohol (97:3), $1 \mathrm{~mL} / \mathrm{min}, \mathrm{t}_{\mathrm{R}}(\mathrm{min}): 21.4(\mathrm{~S}), 23.6(R)$.

\section{4-aminoacetophenone (3a)}

GC-MS m/z (\%) $135\left(\mathrm{M}^{+}, \mathrm{C}_{8} \mathrm{H}_{9} \mathrm{NO} ; 50\right), 120$ (100), 92 (45), 65 (30), 39 (10); HPLC: Chiralcel AS$\mathrm{H}, 30^{\circ} \mathrm{C}, n$-hexane/isopropyl alcohol (85:15), $1 \mathrm{~mL} /$ $\min , t_{R}(\min ): 14.0$.

\section{ACKNOWLEDMENTS}

The authors thank to the Brazilian agencies CAPES and CNPq for fellowships and financial support. 


\section{REFERENCES}

1. Spain, J. C. Annu. Rev. Microbiol. 1995, 49, 523-555.

2. Race, P. R.; Lovering, A. L.; Green, R. M.; Ossor, A.; White, S. A.; Searle, P. F.; Wrighton, C. J.; Hyde, E. I. J. Biol. Chem. 2005, 280, 13256-13264.

3. Aouiche, A.; Sabaou, N.; Meklata, A.; Zitouni, A.; Bijani, C.; Mathieu, F.; Lebrihi, A. World J. Microb. Biot. 2012, 28, 943-951.

4. Anderson, R. C.; Rasmussen, M. A.; Allison, M. J. Appl. Environ. Microbiol. 1993, 59, 30563061.

5. Comasseto, J. V.; Assis, L. F.; Andrade, L. H.; Schoenlein-Crusius, I. H.; Porto, A. L. M. J. Mol. Catal. B: Enzym. 2006, 39, 24-30.

6. Traversi, D.; Degan, R.; De Marcos, R.; Gillig, G.; Pignata, C.; Villani, S.; Bono, R. Environ. Int. 2009, 35, 905-910.

7. Mir, N. A.; Haque, M. M.; Khan, A.; Muneer, M.; Boxall, C. Sci. World J. 2012, 1-8.

8. Kou-san, J.; Parales, R. E. Microbiol. Mol. Biol. Rev. 2010, 74, 250-272.

9. Esteve-Núñez, A.; Caballero, A.; Ramos, J. L. Microbiol. Mol. Biol. Rev. 2001, 65, 335352.

10. Nyanhongo, G. S.; Schroeder, M.; Steiner, W.; Gübitz, G. M. Biocatal. Biotransform. 2005, 23, 53-69.

11. Boelsterli, U. A.; Ho, H. K.; Zhou, S.; Leow, K. Y. Curr. Drug Metab. 2006, 7, 715-727.

12. Paula, F. R.; Serrano, S. H. P.; Tavares, L. C. Quim. Nova 2009, 32, 1013-1020.

13. Hoorrocks, S. M.; Jung, Y. S.; Huwe, J. K.; Harvey, R. B.; Ricke, S. C.; Carstens, G. E.; Callaway, T. R.; Anderson, R. C.; Ramlachan, N.; Nisbet, D. J. J. Food Sci. 2007, 72, M5055.

14. Buschini, A.; Ferrarini, L.; Franzoni, S.; Galati, S.; Lazzaretti, M.; Mussi, F.; Alburquerque, C. N.; Zuchi, T. M. A. D.; Poli, P. J. Parasitol. Res.
2009, 1-11.

15. Roldan, M. D.; Perez-Reinado, E.; Castillo, F.; Moreno-Vivian, C. FEMS Microbiol. Rev. 2008, 32, 474-500.

16. Oliveira, I. M; Bonatto, D.; Henriques J. A. P. Curr. Res., Technol. Educ. Top. Appl. Microbiol. Microbiol. Biotechnol. 2010, 2, 1008-1019.

17. Hannink, N.; Rosser, S. J.; French, C. E.; Basran, A.; Murray, J. A.; Nicklin, S.; Bruce, N. C. Nature Biotechnol. 2001, 19, 1168-1172.

18. Kadiyala, V.; Nadeau, L. J.; Spain, J. C. Appl. Environ. Microbiol. 2003, 69, 6520-6526.

19. Pacheco, A. O.; Kagohara, E.; Andrade, H. L.; Comasseto, J. V.; Crusius, I. H. -S.; Paula, C. R.; Porto, A. L. M. Enzyme Microbial Technol. 2007, 42, 65-69.

20. Suárez-Franco, G.; Hernández-Quiroz, T.; Navarro-Ocaña, A.; Oliart-Ros, R. M.; ValerioAlfaro, G. Biotechnol. Bioproc. Eng. 2010, 15, 441-445.

21. Ferreira, D. A.; Silva, R. C.; Assunção, J. C. C.; de Mattos, M. C.; Lemos, T. L. G.; Monte, F. J. Q. Biotechnol. Bioproc. Eng. 2012, 17, 407 412.

22. Couto, A. N.; Wichmann, F. M. A. Alim. Nutr. 2011, 22, 601-608.

23. Bizerra, A. M. C.; Gonzalo, G.; Lavandera, I.; Gotor-Fernandez, V.; de Mattos, M. C.; de Oliveira, M. C. F.; Lemos, T. L. G.; Gotor, V. Tetrahedron: Assym. 2010, 21, 566-570.

24. Machado, L. L.; Souza, J. S. N.; de Mattos M. C.; Sakata, S.; Cordell, G. A.; Lemos, T. L. G. Phytochem. 2006, 67, 1637-1643.

25. Yu, S.; Quan-yuan, H.; Shao-rong, Y.; Xianming, H. Wuhan Univ. J. Nat. Sci. 2002, 7, 113-116.

26. Assunção, J. C. C.; Machado, L. L.; Lemos, T. L. G.; Cordell, G. A.; Monte, F. J. Q. J. Mol. Catal. B: Enzym. 2008, 52-53, 194-198. 